\section{An Analysis of Code-Mixing Usage in WhatsApp Groups Conversation among Lecturers of Universitas Pamulang}

\author{
1 Haryati \\ 2 Ratu Prayuana
}

12 Universitas Pamulang, Indonesia

\section{Abstract}

This study was aimed to find out the kinds of code-mixing used by lecturers from some departments and the factors of using code mixing. This study was a descriptive qualitative analysis that attempted to describe the kinds of code-mixing and the factors. The participants of this study were lecturers from 4 different groups of Universitas Pamulang. The participants were selected based on the purposive sampling in order to support the research finding. The data were taken from questionnaire and observation on WhatsApp groups to seek the factors and to classify the types of code-mixing. As the results, the writers found the group of Pelatih TOEFL produced 15 congruent lexicalization, 4 insertion and 0 alternation. The group of Penelitian Internal Unpam produced 15 congruent lexicalization, 6 insertion and 2 alternation. The group of Sastra Unpam produced 9 congruent lexicalization, 10 insertion and 5 alternation. The group of Prodi Sasing produced 17 congruent lexicalization, 3 insertion and 5 alternation. In addition, the distribution of questionnaire resulted the factors of applying codemixing on all WhatsApp groups. Bilingualism (38\%), speaker and interlocutor (4\%), situation (5\%), vocabulary (46\%) and prestige $(8 \%)$ are the factors found in Pelatih dan Pengawas TOEFL group. Bilingualism (21\%), speaker and interlocutor (11.11\%), situation $(22 \%)$, vocabulary $(38 \%)$ and prestige $(8 \%)$ are the factors found in Peenelitian Internal Unpam group. Bilingualism (48\%), speaker and interlocutor (5\%), situation (13\%), vocabulary (34\%) and prestige $(0 \%)$ are the factors found in Sastra Unpam group. Bilingualism $(55 \%)$, speaker and interlocutor $(5 \%)$, situation $(7 \%)$, vocabulary $67 \%$ ) and prestige (12\%) are the factors found in Sastra Unpam group.

\section{Keywords}

code-mixing

WhatsApp groups

lecturers' interaction
Ethical Lingua

Vol. 7, No. 2, 2020

ISSN 2355-3448 (Print)

ISSN 2540-9190 (Online)

Corresponding Email

Haryati

haryati.safa@gmail.com

Article's History

Submitted 30 May 2020

Revised 4 August 2020

Revised 17 September 2020

Accepted 27 September 2020

DOI

10.30605/25409190.180

Copyright (C) 2020

The Author(s)

This article is licensed under CC BY-NC-SA 4.0 License 


\section{An Analysis of Code-Mixing Usage in WhatsApp Groups Conversation among Lecturers of Universitas Pamulang}

In digital era, multilingual societies probably produce interaction with the use of their native language and blend it with other languages that they have obtained. The interaction among distinctive cultures in societies leads to the existence of pidgin, creole, bilingualism, multilingualism, code mixing, code switching, and interference. The phenomenon of code mixing occurs when people communicate with others in any places and any topics. It always occurs in humans' life since people were born to interact each other, to share their problem, and to express their feeling whether in small or large communities. Moreover, Indonesian people have code mixing process in their daily interaction. It is clear that Indonesia is well known as multicultural country consisting many diversities of cities, religions, languages, and races, food, tradition, and others. However, Indonesian is used as official language to unit them in communication. Indonesian people are often affected by the existence of regional languages like Sundanese, Javanese, Balinese, and more languages. Therefore, it is one of the reasons why they have code mixing in communication.

This phenomenon also occurs in academic institutions like university. In fact, based on the writers' preliminary observation, lecturers from some departments of Universitas Pamulang also share similar problems in social interaction. Obstacles that lecturers have in social communication are they cannot find out the appropriate words in Indonesian, they hesitate not to deliver obvious meaning, and they are afraid of producing misunderstanding. Initially, it is difficult for lecturers in some departments to utter appropriate words in social communication although they have similar family and educational background, and they share similar first language, Indonesian. Also, the varieties of linguistic background can be claimed as regional varieties which create many distinctive words to refer one object or activity. In this case, they will apply some simple words in order to be understood by the interlocutors. To do the acidity, lecturers have created groups on WhatsApp as media to interact with other friends and colleague and to share some information among their groups. In their communication, they often do code mixing to clarify the meaning or to find the roper words they use. Thus, WhatsApp can be digital media to produce code mixing among lecturers which share distinctive culture (Purba, Suyadi, \& Fitri, 2018).

In general, discussing the relationship between language and society is called as sociolinguistics. It covers several things: how human beings apply language in society, how human beings utter distinctive languages in societies, and how government determine the rules of language in societies. Sociolinguistics is a study which discusses relationship between language use in societies (Chaer \& Agustina, 2004). Sociolinguistics emphasizes on the social groups and the linguistic system in societies and relates to other variables in specific cultures like age, profession, social status, gender, economy, education, and other variables. Those factors lead people to apply code-mixing on their daily interaction.

Initially, code mixing and code switching are mostly used by the multilingual societies which they can apply two or more languages (Chaer \& Agustina, 2004). The explanation of codemixing is stated by Wardhaugh (2010), "most multilingual settings, there are no strict or explicit guidelines for what language to speak." It is clear that speakers or writers expressing 
ideas are not governed by permanent rules how to utter in societies; they are able to utter some languages within one utterance. Furthermore, Safitri, Harida, \& Hamka (2017) stated that "code-mixing is about the combination of a word or phrase in using one language with another language". Here, speakers are able to blend more than language within one sentence; it occurs since they have mastered two or more languages from their family, school, and environment. It can be inferred that code-mixing is a type of how people mix between their native language to another language on their daily conversation through written or spoken interaction.

Furthermore, Musyken (2000, p. 678) stated that the term "code-mixing" refers to all cases where lexical items and grammatical features from two languages appear in one sentence." It means that the speakers or writers blend one or two words freely on their written or spoken interaction. From the previous definition of code mixing, it can be concluded that code-mixing is how different languages are used in on one single conversation or sentence. The implication of why that happened is one of the goals of this study. Code mixing is used by inserting words or pieces in a sentence, and it is applied based on the situation which they have.

Several scholars have described the types of code mixing. Sumarsono \& Pratana (2004) also stated two major kinds of code mixing: inner code - mixing and outer code - mixing. Furthermore, Safitri, Harida, \& Hamka (2017) and Musyken (2000) ssummarize three types of code mixing: 1) insertion, 2) alternation, and 3) congruent lexicalization. This study highlights the types of code-mixing from Musyken (2000). Insertion code-mixing occurs when the speakers insert lexical items into another language. The process takes place when the relationship between languages is unequal. Alternation code-mixing process occurs when the speakers blend one grammatical structure with another language patter. Here, the speaker alternates two language systems within a sentence. Generally, alternation process contrasts to insertion which alternation process does not dominate another grammatical structure. Congruent lexicalization occurs when two languages are linguistically close each other. Because they have similarities in grammatical structure, the speakers are able to move the lexical items freely within a sentence.

Sumarsono \& Partana (2004) describe the factors of code mixing in social interaction. The factors are speakers or writers, interlocutors, the presence of third person, setting of conversation, purpose of conversation, and topic of conversation. Weinreich (1963) also shares some factors of code mixing: internal and external factors. In this research, the writers apply the factors of code mixing introduced by Kim (2006). He states 5 main factors of using code mixing. In the digital era, it is not doubtful that social interaction is affected by the bilingualism or social communities in social media and social communities. Speaker and Interlocutors briefly present the social interaction among people: intimate or distance relationship. Furthermore, code mixing occurs in both formal and informal situation. People insert word or phrases in their written or spoken utterances. People undeniably lack appropriate words or vocabulary in one language. This inability leads people to mix their language with another language to express or deliver the messages. The millennial era delivers people the varieties of languages especially English as the lingua franca to bridge the communication. Therefore, many people use English in their social interaction on social media including WhatsApp to show off their prestige.

The digital era and the technological development affect people to use code-mixing on the social media including WhatsApp. Scholars provided some recent studies about the use of code-mixing on WhatsApp groups. Idris \& Shabri (2017) found that "the students mostly code 
mix using their L1 (Malay) and English. Insertion of words was the mostly used style of codemixing by the respondents." This finding is affected by the second language they have, Malay. The students have obtained their mother tongue, they have got the exposure of using English as second language. Therefore, it leads to the use of code-mixing more often. Safitri, Harida, \& Hamka (2017) found that "code mixing can be represented in some of status and comments". In addition, Yunus (2010, p. 70) explained "WhatsApp as social media which is as a medium connected to the internet network that allows users to communicate in the virtual world or online". Here, millennial people are excited to use WhatsApp to inform something and unconsciously they apply code-mixing on the chatting process.

According to above elaboration, the previous studies focused on analyzing the use of codemixing on WhatsApp and discussed the most often commonly used of code-mixing; however, they did not attempt to investigate and describe the factors why people applied code-mixing. Moreover, the studies focused on analyzing code-mixing used by the students. Therefore, the writers attempted to expand the research by analyzing the types of code-mixing used by the lecturers from some distinct faculties on WhatsApp, determining the most commonly, investigating the factors of code-mixing, and ranking those factors. In brief, the writers are going to analyze: the kinds of code mixing used by lecturers at English Department and other departments through their groups on WhatsApp, determining the most absorption words the lecturers used on WhatsApp, and the factors of applying code-mixing.

\section{Method}

The writers used a qualitative approach to conduct their research. Stake (2010) defines "the qualitative research relies on human perception about the subjects and understanding". It is a kind of social study which collects data without considering the numerical results, and it helps people understand social condition. Sugiyono (2009) also argues that qualitative approach is a kind of research methodology which is based on the philosophy of post positivism applied to analyze the research object. Therefore, the study was a descriptive qualitative analysis that attempted to describe the kinds of code-mixing applied by the lecturers and the factors of code-mixing process. In line, Meleong (2005) highlights descriptive analysis is the elaboration of results in the form of written words from the objects that are analyzed. Furthermore, the type of this study is in the form of description of the data and result, opinion, and observation rather than numerical data. In addition, Satoto (1999) stated the descriptive analysis is the method used to interpret the obtained data specifically and then grouped and classified into its category.

The participants of this research were the English lecturers of Universitas Pamulang who are joining some groups: Sastra Unpam, Penelitian Internal Unpam, Pelatih TOEFL, and Prodi Sasing. The total of the participants was about 405 lectures; they are from some departments: English Literature, Management, Law, Secretary, Accountancy, and Engineering. The writers used two instruments to obtain the data: the chat of some groups (four groups) of several faculties of Universitas Pamulang on WhatsApp and questionnaire to seek the main factors of code-mixing process.

To conduct the research, the writers selected four active groups in some distinctive faculties. To analyze the kinds of code-mixing and find out the factors of using code-mixing on digital interaction, the writers used the theory from Musyken (2000) and Kim (2006). Musyken classifies 3 major kinds of code-mixing: insertion, alternation, and congruent lexicalization. Kim highlights 5 main factors: bilingualism, speaker and interlocutors, situation, vocabulary, 
and prestige. These points were specifically interpreted in the findings. Next, the writers observed the groups routinely for about two months. The observation process was done by noting some sentences using code mixing. The writers noted down all code-mixing words produced by all lecturers. Then, the writers classified the kinds of code mixing used by the lecturers and found out the most often code mixing used by the lecturers. Next process, the writers distributed questionnaire to each lecturer to seek the main factor of code-mixing process on their interaction. Then, the writer noted down all factors and identify them into some classes. After classifying the factors, the writers found out the most dominant factor. After gaining the data, the writer noted them in research findings.

\section{Results}

The writers will reveal the two main points that will be dealt after classifying the types of codemixing and analyzing the factors. The first is the classification of code-mixing types from four groups: Pelatih TOEFL, Penelitian Internal Unpam, Sastra Unpam, and Prodi Sasing, and the second is the factors of code-mixing use on WhatsApp.

\section{Pelatih TOEFL Group}

Tabel 1. Pelatih TOEFL

\begin{tabular}{|c|c|c|c|}
\hline NO & PARTICIPANTS & SENTENCES & $\begin{array}{l}\text { TYPES OF CODE } \\
\text { MIXING }\end{array}$ \\
\hline \multirow[t]{2}{*}{1} & P1 & $\begin{array}{l}\text { sosialisasikan di group dosen dan karyawan di prodi masing- } \\
\text { masing. }\end{array}$ & $\begin{array}{l}\text { Congruent } \\
\text { Lexicalization }\end{array}$ \\
\hline & & Ooo sekarang dollar Amerika 16000 per jam ya? & $\begin{array}{l}\text { Congruent } \\
\text { Lexicalization }\end{array}$ \\
\hline 2 & P2 & Trainner nya ya & $\begin{array}{l}\text { Congruent } \\
\text { Lexicalization }\end{array}$ \\
\hline 3 & P3 & Assalamualaikum Wr Wb.. ibu bapa ini link modulnya yah & $\begin{array}{l}\text { Congruent } \\
\text { Lexicalization }\end{array}$ \\
\hline 4 & P4 & sy blm punya boleh di share? & $\begin{array}{l}\text { Congruent } \\
\text { Lexicalization }\end{array}$ \\
\hline 5 & P5 & Daripada stress korona kita nyanyi dulu dah & $\begin{array}{l}\text { Congruent } \\
\text { Lexicalization }\end{array}$ \\
\hline 6 & P6 & Sama. Ga pernah bolos, e learning create ok. Ternyata . & Insertion \\
\hline \multirow[t]{2}{*}{7} & P7 & Kuotanya Khusus untuk elearning saja & $\begin{array}{l}\text { Congruent } \\
\text { Lexicalization }\end{array}$ \\
\hline & & $\begin{array}{l}\text { Monggo, yg pake simpati, 30gb free Khusus untuk Web e } \\
\text { learning }\end{array}$ & $\begin{array}{l}\text { Congruent } \\
\text { Lexicalization }\end{array}$ \\
\hline 8 & P8 & Bantu subscribe like $\mathrm{n}$ komen Ya bapak ibu & Insertion \\
\hline \multirow[t]{2}{*}{9} & P9 & Naon Prince & Insertion \\
\hline & & Copy di sini ya & $\begin{array}{l}\text { Congruent } \\
\text { Lexicalization }\end{array}$ \\
\hline \multirow[t]{2}{*}{10} & P10 & Dgn E-Learning sdh cukup & $\begin{array}{l}\text { Congruent } \\
\text { Lexicalization }\end{array}$ \\
\hline & & Nganu Pak Boss ku & Insertion \\
\hline
\end{tabular}




\begin{tabular}{|c|c|c|c|}
\hline NO & PARTICIPANTS & SENTENCES & $\begin{array}{l}\text { TYPES OF CODE } \\
\text { MIXING }\end{array}$ \\
\hline 11 & P11 & $\begin{array}{l}\text { untuk membantu distance learning, saya telah merilis fitur } \\
\text { terbaru pada aplikasi saya, English Grammar Expert, yaitu, } \\
\text { Explainer Video. Mahasiswa bisa belajar berbagai topik } \\
\text { grammar dan melakukan self-assessment. Semoga bermanfaat. }\end{array}$ & $\begin{array}{l}\text { Congruent } \\
\text { Lexicalization }\end{array}$ \\
\hline 12 & P12 & full timer, mengajar senin - jumat & $\begin{array}{l}\text { Congruent } \\
\text { Lexicalization }\end{array}$ \\
\hline 13 & P13 & $\begin{array}{l}\text { Luar biasa....ayo bu terus posting puisinya....saya sangat } \\
\text { menunggu }\end{array}$ & Insertion \\
\hline 14 & P14 & Yang request pak Ketua, bu & Insertion \\
\hline 15 & P15 & $\begin{array}{l}\text { yang tidak dapat Certificate boleh ngulang atau gimana Pak } \\
\text { Bona }\end{array}$ & $\begin{array}{l}\text { Congruent } \\
\text { Lexicalization }\end{array}$ \\
\hline 16 & P16 & Bolehkah kita minta bocoran lewat WA secara personal? Ji & $\begin{array}{l}\text { Congruent } \\
\text { Lexicalization }\end{array}$ \\
\hline
\end{tabular}

Based on the above table, the group produced 15 statements included in congruent lexicalization and 4 statements as insertion. Some code mixing of congruent lexicalization are "Assalamualaikum. ...di group dosen dan karyawan di prodi masing-masing." This statement has the process of code mixing. The participants applied "group" on her chat on WhatsApp. It is obvious that the word group has similar word with the utterance of Indonesian. Indonesians utter "grup"; they drop "o", but they have similar pronunciation. Next, "Ooo sekarang dollar mencapai 16000 per jam ya?". The participant used "dollar" since it has become the common word and each individual in the world knows about it. It has been familiar among people because it is one of the famous currencies in the world. Moreover, "Kuotanya Khusus untuk $\boldsymbol{e}$ learning saja" is another statement having the congruent lexicalization. "E learning" is one of common word in this digital era, and it has been using in educational institutions. Another statement of congruent lexicalization is "yang tidak dapat Certificate boleh ngulang atau bagaimana Pak Bona?". "Certificate" has similar sound or word with Indonesian "sertifikat". On the other hand, the participants of the group also produced the code mixing of insertion. "Sama. Ga pernah bolos, e learning create ok. Ternyata." It is the example of insertion. The participant inserted lexical items that are familiar among members on group within sentence which is unequal grammatical sentence. The last, "Yang request pak Ketua, bu", the participant inserted an alien lexical word within Indonesian to clarify the meaning.

\section{Penelitian Internal Unpam Group}

Table 2. Penelitian Internal Unpam

\begin{tabular}{llll}
\hline NO & PARTICIPANTS & SENTENCES & $\begin{array}{l}\text { TYPES OF CODE } \\
\text { MIXING }\end{array}$ \\
\hline 1 & P1 & $\begin{array}{l}\text { Bagi yang belum upload perbaikan proposal dimohon } \\
\text { melaksanakan PERBAIKAN proposal dengan menemui } \\
\end{array}$ & $\begin{array}{l}\text { Congruent } \\
\text { reviewer masing masing untuk konsultasi dan MINTA } \\
\end{array}$ \\
& $\begin{array}{l}\text { Persetujuan/TANDATANGAN Reviewer, Kemudian Upload } \\
\text { perbaikan proposal pada menu perbaikan proposal } \\
\text { sintias.unpam.ac.id. }\end{array}$ & \\
& & \\
\hline
\end{tabular}


.Bagi yg sudah upload tapi statusnya tidak Valid mohon di cek kembali.. dan dilengkapi kekuranganya kemudian

Congruent Upload ulang.

Lexicalization

Komunikasi perbaikan proposal dan ttd reviewer bisa melalui daring (email dll)

Berikut Data status dosen per prodi yang sdh upload perbaikan dan yang belum.

Congruent Lexicalization

Bisa via email pa.. mohon bantuan reviewer untuk di scan dan di email

Congruent

Lexicalization

Tetap upload perbaikan pa.. dan minta ttd reviewer

Congruent

Lexicalization

Berikut contoh perbaikan proposal yang sdh kami

Congruent nyatakan valid (ada ttd reviewer di halaman terakhir).

Terimakasih

User dan password sama dengan input nilai pak

Lexicalization

Congruent

Lexicalization

kami informasikan bagi yang tidak lolos kami mohon untuk segera input proposalnya di sistem sintias.unpam.ac.id

\section{Congruent} Lexicalization

Bagi bpk/ibu dosen yang belum unggah atau blm valid

Congruent masih kita tunggu

Lexicalization

Berikut yg sudah mengumpulkan laporan akhir penelitian dan akan kami transfer.

Congruent Lexicalization

Yang belum mohon segera..terimakasih

Laporan Akhir hard cover sebanyak 2 rangkap dan soft filenya

Output luaran wajib atau setidaknya draft artikelnya

Insertion

Insertion

Saya harus upload ulang???

Congruent

Lexicalization

saya sudah mengirimkan perbaikan ke reviewer dan masih menunggu direspon oleh reviewer

Congruent

Lexicalization

Mohon arahan pak,bagaimana dengan masa isolasi 2 Insertion minggu karena virus Corona sekarang ini?

$5 \quad P 5$

$6 \quad P 6$

$7 \quad \mathrm{P} 7$

$8 \quad$ P8

$9 \quad \mathrm{Pg}$

$10 \quad \mathrm{P} 10$
Artikel disesuaikan dengan template dan langsung submit via webnya.

Jika nilai sudah di atas Passing Grade bagaimana ya Pak Ali ?

Apa sudah diganti usernamenya dan passwordnya?

Pak Ibnu just info kemarin sy sdh serahkan hard copynya ke bu dewi dan pak Toni..yg soft jg sdh sy email sabtu lalu dan sudah di confirmed sama p Toni..

Baik pak ibnu, akan dicoba ... Terimakasih fast responnya

Pak ali dan tim mohon advicenya mengacu pada info ini bahwa deadline input laporan
Insertion

Congruent Lexicalization

Insertion

Congruent Lexicalization

Congruent Lexicalization Insertion 


\begin{tabular}{llll}
\hline NO & PARTICIPANTS & SENTENCES & $\begin{array}{l}\text { TYPES OF CODE } \\
\text { MIXING }\end{array}$ \\
\hline 11 & P11 & Baik Pak Ibnu. Segera dikirim kan scan validity sheet & Alternation \\
12 & P12 & $\begin{array}{l}\text { Dilampirkan data para peneliti, bagi yang sudah please } \\
\text { send email (softcopy) the result of research }\end{array}$ & Alternation \\
& & & \\
\hline
\end{tabular}

Based on the above table, the group produced 15 statements included in congruent lexicalization and 6 statements as insertion and 2 statements are alternation. The code mixings of insertion are "Baik Pak Ibnu, akan dicoba ... Terimakasih fast responnya". This statement has insertion code mixing since the participant inserted one lexical item that has ungrammatical structures; it has no relation with both languages.

"Pak Ali dan tim mohon advicenya mengacu pada info ini bahwa deadline input laporan akhir pkm jatuh pada tanggal 15 Jan." This statement is also claimed as insertion process of code mixing. He inserted those words without considering the grammatical sentence

The code mixings of alternation are Baik Pak Ibnu. Segera dikirim kan scan validity sheet. The participant mixed English phrase within his sentence, and it did not distract the grammatical structure. Here the participant also alternates two structures of languages undistinguishably; He substitutes the second phrase in English. Next, Dilampirkan data para peneliti, bagi yang sudah please send email (softcopy) the result of research. The participants did similar process with the previous participant.

The code mixings of congruent lexicalization are: Apa sudah diganti usernamenya dan passwordnya?. The participant blended password and username in English and nya in Indonesian. It is clear that he inserted one lexical item (word), and it has proper grammatical structure which username and password are nouns in English. Moreover, Berikut yg sudah mengumpulkan laporan akhir penelitian dan akan kami transfer. This statement presents congruent lexicalization because the participant placed 'transfer'; its functional word is as verb. The clause 'akan kami transfer' has the pattern of subject and predicate in Indonesian, and transfer is placed as verb; hence, it delivers proper grammatical structure.

\section{Sastra Unpam Group}

Table 3. Sastra Unpam

\begin{tabular}{llll}
\hline N0 & PARTICIPANTS & SENTENCES & $\begin{array}{l}\text { TYPES OF CODE } \\
\text { MIXING }\end{array}$ \\
\hline 1 & P1 & Materi Workshop Online Penulisan Jurnal Scopus & Insertion \\
& Meeting 9 dst silahkan ibu ganti dengan meeting ... & Insertion \\
& Ada ko bu Eka, baru 19 create nya harusnya 30 & Insertion \\
& Silakan bpk ibu... sambil wfh bisa mengikuti live streaming & Congruent \\
& & acara seminar dan workshop ... & Lexicalization \\
& & Allah knows the best bu kalau 3 sks bu Lisa banyak & Alternation \\
& & Thanks Ibu Christy for the info. & Alternation \\
& & Saya juga nyaman dengan retorikanya Bu. Sejuk. & Insertion \\
& Pak dekan, next time audio diedit lagi biar ga terlalu noise & \\
& pak. & \\
& &
\end{tabular}




\begin{tabular}{|c|c|c|c|}
\hline NO & PARTICIPANTS & SENTENCES & $\begin{array}{l}\text { TYPES OF CODE } \\
\text { MIXING }\end{array}$ \\
\hline 3 & P3 & Must be great banget itu. & Alternation \\
\hline \multirow[t]{3}{*}{4} & P4 & Maksudnya blm di comment & Insertion \\
\hline & & Nuhun pak Fajar & Insertion \\
\hline & & Sy on going masih 1 kelas lagi & \\
\hline 5 & P5 & Bapak dan Ibu berikut hasil rekap create sampai pukul. & Insertion \\
\hline \multirow[t]{2}{*}{6} & P6 & $\begin{array}{l}\text { Thanks in advance for your help, saya akan langsung kirim } \\
\text { segera }\end{array}$ & Alternation \\
\hline & & Saya belum ke data Pak? & Insertion \\
\hline \multirow[t]{2}{*}{7} & P7 & Akan dikomunikasikan ke editornya Pak & $\begin{array}{l}\text { Congruent } \\
\text { Lexicalization }\end{array}$ \\
\hline & & $\begin{array}{l}\text { Hati hati menjelang puasa dan lebaran kejahatan biasanya } \\
\text { meningkat apalagi musim unpaid leave dan PHK. }\end{array}$ & Insertion \\
\hline 8 & P8 & $\begin{array}{l}\text { baseball bat), nomor telepon security kompleks, nomor } \\
\text { telp tetangga dan Pak RT. }\end{array}$ & $\begin{array}{l}\text { Congruent } \\
\text { Lexicalization }\end{array}$ \\
\hline \multirow[t]{2}{*}{9} & P9 & Apa itu, surat tilang ? So We must stay home & Alternation \\
\hline & & $\begin{array}{l}\text { Aduh pak fajar baru bisa merespond nih, jadi besok siang } \\
\text { ada report ya. mhsw juga belum jawab semua }\end{array}$ & $\begin{array}{l}\text { Congruent } \\
\text { Lexicalization }\end{array}$ \\
\hline 10 & P10 & Allah maha mendengar dan insya Allah corona.... & $\begin{array}{l}\text { Congruent } \\
\text { Lexicalization }\end{array}$ \\
\hline 11 & P11 & $\begin{array}{l}\text { Ide yg bagus terimakasih postingan dan ajakan semoga } \\
\text { menjadi amal kita semua }\end{array}$ & $\begin{array}{l}\text { Congruent } \\
\text { Lexicalization }\end{array}$ \\
\hline 12 & $\mathrm{P} 12$ & ...dari virus corona ini....Aamiin Yaa Rabbal Aalamiin & Insertion \\
\hline 13 & $\mathrm{P} 13$ & lampiran produk dan harga di UniMart yang bisa diorder & $\begin{array}{l}\text { Congruent } \\
\text { Lexicalization }\end{array}$ \\
\hline 14 & P14 & Ibu langsung click toko Rani center nanti sudah ada & $\begin{array}{l}\text { Congruent } \\
\text { Lexicalization }\end{array}$ \\
\hline 15 & P15 & ...walaupun dosen sdh menginput nilai tersebut. & $\begin{array}{l}\text { Congruent } \\
\text { Lexicalization }\end{array}$ \\
\hline
\end{tabular}

Based on the above table, the group produced 9 statements included in congruent lexicalization and 10 statements as insertion and 5 statements are alternation. The code mixings of insertion are Yaa Allah...lindungi lah kami dan mohon di sembuhkan ayahanda nya dari virus corona.... It includes the insertion of two lexical words 'virus corona'. The participant inserted these words without considering the grammatical structure. He inserted the English term within Indonesian; however, he stated the wrong English words "corona virus". Furthermore, Saya belum ke data Pak?. The process of code-mixing in this statement is insertion. The participant inserted 'data' within Indonesian; however, it was placed improperly since ' $k e$ ' in Indonesian must be followed by the adverb of place. However, the participant placed 'data' as noun after ' $k e$ '; it is improper placement.

The first statement claimed as alternation is Apa itu, surat tilang? So We must stay home. Here, the participant interchanged both grammatical structures, or it can be revealed that he used Indonesian in the first phrase and English as the second structure. Moreover, the next statement having alternation code-mixing process is Thanks in advance for your help, saya akan langsung kirim segera. The participants combined both English and Indonesian to form 
a readable sentence. The code mixings of Congruent Lexicalization are ...walaupun dosen sdh menginput nilai tersebut. This statement has 'menginput' as the code-mixing lexical item. The participant mixed affix 'meng' in Indonesian with 'input' in English; in Indonesian, if people use 'meng' as affix, it must be followed by verb, and 'input' is a proper word class to attach. Another congruent lexicalization code-mixing is "...order dari rumah...." In this statement, the participant mixed different lexical item into a shared grammatical structure (Indonesian), but he considered the structure of the language. It is congruent lexicalization as 'order' is verb word class, and it matches with the previous phrases that the word 'bisa' in Indonesian has to be followed by verb word class (order).

\section{Prodi Sasing Group}

Table 4. Prodi Sasing

\begin{tabular}{|c|c|c|c|}
\hline NO & PARTICIPANTS & SENTENCES & $\begin{array}{l}\text { TYPES OF CODE } \\
\text { MIXING }\end{array}$ \\
\hline \multirow[t]{4}{*}{1} & \multirow[t]{4}{*}{$\mathrm{P} 1$} & Ada kepala Ildikti jg bapak ibu & \multirow{2}{*}{$\begin{array}{l}\text { Congruent } \\
\text { Lexicalization }\end{array}$} \\
\hline & & Jadi silahkan mendaftar segera. Ini info dari pak ali & \\
\hline & & Aduh tp dijam yg sama ada zoom meeting kemahasiswaan & $\begin{array}{l}\text { Congruent } \\
\text { Lexicalization }\end{array}$ \\
\hline & & Alhamdulillah bisa meramaikan seminar international & Insertion \\
\hline 2 & $\mathrm{P} 2$ & Tapi ini untuk TEFL gantinya adalah teaching method & $\begin{array}{l}\text { Congruent } \\
\text { Lexicalization }\end{array}$ \\
\hline 3 & P3 & $\begin{array}{l}\text { Ini karena Ismaya mau tutup semua restaurant mereka jadi } \\
\text { habisin stock }\end{array}$ & $\begin{array}{l}\text { Congruent } \\
\text { Lexicalization }\end{array}$ \\
\hline \multirow[t]{3}{*}{4} & \multirow[t]{3}{*}{ P4 } & Maaf $\mathrm{Bu}$, ini lg Maaf Bu, ini lg berexperiment dgn foto & Insertion \\
\hline & & Thank you for the sharing, Bu Sari & Alternatiom \\
\hline & & $\begin{array}{l}\text { Punten, ini yg prodi non-English kah? Just want to make } \\
\text { sure? }\end{array}$ & Alternation \\
\hline 5 & P5 & Ini photo siapa bu ? & $\begin{array}{l}\text { Congruent } \\
\text { Lexicalization }\end{array}$ \\
\hline \multirow[t]{3}{*}{6} & \multirow[t]{3}{*}{ P6 } & $\begin{array}{l}\text {..tentang module of public speaking, meeting } 11 \text {. It has } \\
\text { inappropriate content. }\end{array}$ & Alternation \\
\hline & & Masya Allah Bapak Ibu... I am proud of you all & Alternation \\
\hline & & Siap bu Sari...I will do try... & Alternation \\
\hline \multirow[t]{2}{*}{7} & \multirow[t]{2}{*}{ P7 } & $\begin{array}{l}\text { Berarti udah bisa daftar sekarang untuk ikut test di akhir } \\
\text { April nanti? }\end{array}$ & $\begin{array}{l}\text { Congruent } \\
\text { Lexicalization }\end{array}$ \\
\hline & & Bu Amy, coba ketik lagi nama web nya secara manual.. & $\begin{array}{l}\text { Congruent } \\
\text { Lexicalization }\end{array}$ \\
\hline 8 & P8 & Kita harus pakai telegram & $\begin{array}{l}\text { Congruent } \\
\text { Lexicalization }\end{array}$ \\
\hline 9 & P9 & menyelenggarakan SEMINAR ONLINE dengan tema OJS & Insertion \\
\hline 10 & P10 & $\begin{array}{l}\text { Abaikan saja kalau sudah bu. Itu hanya untuk reminder dari } \\
\text { warek } 1\end{array}$ & $\begin{array}{l}\text { Congruent } \\
\text { Lexicalization }\end{array}$ \\
\hline 11 & P11 & $\begin{array}{l}\text { Bisa bu.. refresh dlu punya bu Amy. Mudah2an jadi bisa } \\
\text { kembali }\end{array}$ & $\begin{array}{l}\text { Congruent } \\
\text { Lexicalization }\end{array}$ \\
\hline
\end{tabular}




\begin{tabular}{|c|c|c|c|}
\hline NO & PARTICIPANTS & SENTENCES & $\begin{array}{l}\text { TYPES OF CODE } \\
\text { MIXING }\end{array}$ \\
\hline 12 & P12 & Waalaikumsalam. Saya bisa access Bu dan lancar jaya & $\begin{array}{l}\text { Congruent } \\
\text { Lexicalization }\end{array}$ \\
\hline \multirow[t]{2}{*}{13} & P13 & $\begin{array}{l}\text { UNPAM tetap exist dan berkarya untuk Negeri walaupun } \\
\text { dengan kondisi saat ini. }\end{array}$ & $\begin{array}{l}\text { Congruent } \\
\text { Lexicalization }\end{array}$ \\
\hline & & $\begin{array}{l}\text { Dalam rangka menyikapi perkembangan covid } 19 \text { ini,kita } \\
\text { semua berikhtiar dengan social/physical distancing. ... }\end{array}$ & $\begin{array}{l}\text { Congruent } \\
\text { Lexicalization }\end{array}$ \\
\hline \multirow[t]{2}{*}{14} & P14 & Notificationnya sudah sesuai pak & Congruent \\
\hline & & Thanks, pak Annas 扐兔 & Lexicalization \\
\hline \multirow[t]{2}{*}{15} & P15 & lya Bu. Semua notif kalender harus diset ulang & $\begin{array}{l}\text { Congruent } \\
\text { Lexicalization }\end{array}$ \\
\hline & & $\begin{array}{l}\text { Apakah waktu datangnya notifikasi }(\mathrm{H}-1 \text { at } 9 \mathrm{am}) \text { sudah } \\
\text { sesuai harapan Mohon feedbacknya. }\end{array}$ & $\begin{array}{l}\text { Congruent } \\
\text { Lexicalization }\end{array}$ \\
\hline 16 & P16 & Berikut rangkuman jadwal online learning untuk prodi & $\begin{array}{l}\text { Congruent } \\
\text { Lexicalization }\end{array}$ \\
\hline
\end{tabular}

Based on the above table, the group of Prodi Sasing produced 17 statements included in congruent lexicalization and 3 statements as insertion and 5 statements are alternation.

The code mixings of Insertion are Kami dari LPPM akan menyelenggarakan SEMINAR ONLINE dengan tema OJS. The participant inserted 'seminar online' as the lexical items; it delivers noun word class, but it was placed by the participants improperly. Moreover, ... seminar international is the second statement consisting insertion code-mixing process. In fact, the above statement present similar instance with the second statement. The participant integrates the lexical item "international" as the English word into another language, Indonesian.

The code mixings of Alternation are Masya Allah Bapak Ibu... I am proud of you all since it consists the alternation of structures of both languages: Indonesian and English within a sentence. Furthermore, the grammatical structure does not deliver the leading structure. Furthermore, Ok Ms Sari... will do try... The participant blended both English and Indonesian grammatical structures equally. The code mixings of Congruent lexicalization are Berikut rangkuman jadwal online learning.... The participant involved the lexical words from one language into another language which the pattern of the language is linguistically close to each other. For the second sentence is Saya bisa access Bu dan lancar jaya. The participant here inserted one English lexical item 'access' into Indonesian. It is clear that in Indonesian's grammatical structure, the word 'bisa' should be followed by verb, and the above sentence has the insertion of 'access' into proper grammatical pattern.

\section{The Factors of Code Mixing among the Groups}

Pelatih TOEFL group has 144 members; however, according to the result of online questionnaire, there were only 85 lecturers who participated to complete the questionnaire. The most dominant factor of using code-mixing on this group was vocabulary bilingualism and communities, and prestige. The members of this group applied code-mixing since they lack of proper lexical items. Sometimes, it is complicated for them to find the proper words to utter or write something. This inability leads people to mix their language with another language to express or deliver the messages. In addition, most of them applied code-mixing 
because the influence of bilingualism and communities that they join. In this millennial era, people are not able to avoid the mastery of the existence of multilingualism. People can utter some languages; therefore, it unconsciously affects their interaction.

Table 5. Percentage of Pelatih TOEFL

\begin{tabular}{llr}
\hline Factors & Numbers & Percentage \\
\hline Bilingualism or Social Communities & 32 & $37.65 \%$ \\
Speaker and Interlocutors & 3 & $3.53 \%$ \\
Situation & 4 & $4.71 \%$ \\
Vocabulary & 39 & $45.88 \%$ \\
Prestige & 7 & $8.23 \%$ \\
\hline
\end{tabular}

Penelitian Internal Unpam group has 102 members; however, according to the result of online questionnaire, there were only 63 lecturers who participated to complete the questionnaire. The distribution is illustrated below:

Table 6. Percentage of Penelitian Internal Unpam

\begin{tabular}{llr}
\hline Factors & Numbers & Percentage \\
\hline Bilingualism or Social Communities & 13 & $20.63 \%$ \\
Speaker and Interlocutors & 7 & $11.11 \%$ \\
Situation & 14 & $22.22 \%$ \\
Vocabulary & 24 & $38.10 \%$ \\
Prestige & 5 & $7.94 \%$ \\
\hline
\end{tabular}

In Penelitian Internal Unpam, the most dominant factors are vocabulary bilingualism and communities and speaker and interlocutors. The members of this group also applied codemixing since they lack of proper lexical items or vocabulary. In addition, most of them applied code-mixing because the influence of bilingualism and communities that they join. Although the lecturers are not from English department, they had been familiar with many English words because the technological era insist to master English. The last, the lecturers applied code-mixing as they the members of the group have close relationship although they are from distinctive faculties. The intimate relationship among members are created by the humble characteristics of LPPM personals; the relationship encourages people to mix the languages in one communication.

Table 7. Percentage of Prodi Sasing

\begin{tabular}{llr}
\hline Factors & Numbers & Percentage \\
\hline Bilingualism or Social Communities & 32 & $55.17 \%$ \\
Speaker and Interlocutors & 3 & $5.17 \%$ \\
Situation & 4 & $6.90 \%$ \\
Vocabulary & 39 & $67.24 \%$ \\
Prestige & 7 & $12.07 \%$ \\
\hline
\end{tabular}


In Prodi Sasing group, the most dominant factors are vocabulary, Bilingualism or Social Communities and prestige. All members in the group are from English Department; as a result, they have achieved the English mastery or vocabulary. The vocabulary comprehension had affected the lecturers to produce code-mixing in their social interaction. The lecturers present some distinctive languages, or they are called multilingual language users. he last was prestige factor. The millennial era promotes people the varieties of languages especially English as the lingua franca to bridge the communication. Therefore, many people use English in their social interaction on social media including WhatsApp to show off their prestige. They argued that English was used as a tool to show off their intellectuality and intelligence to publics.

Table 8. Percentage of Sastra Unpam

\begin{tabular}{llr}
\hline Factors & Numbers & Percentage \\
\hline Bilingualism or Social Communities & 30 & $48.39 \%$ \\
Speaker and Interlocutors & 3 & $4.84 \%$ \\
Situation & 8 & $12.90 \%$ \\
Vocabulary & 21 & $33.87 \%$ \\
Prestige & 0 & $0 \%$ \\
\hline
\end{tabular}

Sastra Unpam group has 97 members; however, according to the result of online questionnaire, there were only 62 lecturers who participated to complete the questionnaire. According to the above description, it can be revealed that the most dominant factors are Bilingualism or Social Communities, vocabulary and situation. This group also has introduced many common words among groups: online learning, create, share, module, zoom, sorry, thanks, join, covert, meeting, username, password, and many other regular words among lecturers. Because of those familiar words, many lectures apply those word when chatting with others through WhatsApp. The last factor is situation of online interaction. Basically, code mixing occurs in both formal and informal situation. This informal situation leads them to apply code mixing, and the common topic may break the ice on their interaction.

\section{Discussion}

The four groups mostly produced code-mixing in kind of congruent lexicalization like dollar, E-learning, certificate, group, and others, insertion like fast, advice, and alternation like thanks in advance for the help, and others. They produced code-mixing since those words have become the common word, and they have been familiar among societies. Furthermore, the participants are affected by the use of bilingualism: Bahasa and English which share similar dialect within language use (Musyken, 2000). Most of English words have been common words in this digital era especially in educational institutions like E-learning, create, data, and others. This leads the participant to mix one word within sentence, and it shares grammatical structure of both languages.

Code-mixing also occurs when people blend one structural sentence with another pattern of language. The inclusion of two language systems within a sentence or the process of blending of two different grammatical sentences equally. In brief, alternation code-mixing process does not have any dominating language (Musyken, 2000). This situation is equivalent with the ideas of Claros \& Isharyanti (2009) stating congruent lexicalization is the situation where both languages: Bahasa and English share the grammatical pattern that can be completed with 
another lexical item from one of languages. Moreover, the process of code mixing done by the participant is perceived as borrowing word from another language (Musyken, 2000). Therefore, participants are in the circle of multilingualism, and it is in line with Liu (2006) who describes this process of code-mixing frequently occurs between multilingual speakers. People having some distinctive languages, or they are called multilingual language users.

Hoffmann (1991) also shares similar argument that people living in bilingual ad multilingual regions have high possibility to mix their language with another language system. The multilingual speakers are sometimes complicated for them to find the proper words to utter or write something because many people have been introduced a lot of lexical items or words regularly including upload, email, download, reviewer, proposal, many other common words; therefore, it affects them to utter those common on their group. Mackeys' (cited in Chaer \& Agustina, 2004, p. 128) study explores that "integration is element of other language used in specific language considered to be a citizen of the language." Kim (2006) also shares similar perceptive regarding the factors of code-mixing usage: improper vocabulary, multilingualism, relationship between speakers, and someone's prestige.

\section{Conclusion}

Briefly, the main purposes of this study were to find out the kinds of code-mixing used by lecturers joined the four WhatsApp groups and analyze the factors why they applied codemixing in their digital interaction. As the results, the Unpam lecturers in four WhatsApp groups produced distinctive kinds of code mixing. Firstly, the group of Pelatih TOEFL produced 15 congruent lexicalization and 4 insertion. Secondly, the group of Penelitian Internal Unpam produced 15 congruent lexicalization, 6 insertion and 2 alternation. Next, the group Sastra Unpam produced 9 congruent lexicalization, 10 insertion and 5 alternation. The last, the group of Prodi Sasing produced 17 congruent lexicalization, 3 insertion, and 5 alternation. Furthermore, most lecturers applied code-mixing in their interaction due to some factors (top 3). The lecturers in Pelatih TOEFL group revealed that the most dominant factor was vocabulary $(45,88 \%)$, the following factor was bilingualism and communities $(37.65 \%)$, and the third was 35 prestige (8.23\%). The lecturers in Penelitian Internal Unpam revealed that the most dominant factor was vocabulary $(38,10 \%)$, the following factor was bilingualism and communities (20.63\%), and the third was speaker and interlocutors $(11.11 \%)$. Next, the lecturers in Sastra Unpam group revealed that the most dominant factor was Bilingualism or Social Communities $(48,39 \%)$, the following factor was vocabulary $(33.87 \%)$, and the third was situation (12.90\%). Lastly, the lecturers in Prodi Sasing group revealed that the most dominant factor was vocabulary $(67,24 \%)$, the following factor was Bilingualism or Social Communities $(55.17 \%)$, and the third was prestige (12.07\%). The writers really expect that further studies that discuss the same thing can provide greater expansion for better results and the results of this study may be used as a provision of information for further research.

\section{Acknowledgment}

We would like to thank to the lecturers of four groups of Universitas Pamulang for their assistance with the data collection. 


\section{References}

Chaer, A. \& Agustina, L. (2004). Sosiolinguistik Perkenalan Awal. Jakarta: Rineka Cipta

Claros, M. S. C., \& Isharyanti, N. (2009). Code-switching and code-mixing in Internet chatting: between 'yes', 'ya', and 'si'-a case study. The JALT CALL Journal, 5(3), 6778. https://doi.org/10.29140/jaltcall.v5n3.87

Hoffmann, C. (1991). An Introduction to Bilingualism. London: Longman.

Idris, N. \& Shabri, N. H. (2017). Code-Mixing and Code-Switching Practice Among UiTM Undergraduates Students in Face-to-Face and Whatsapp Group Application. Al-Lisan International Journal for Linguistic and Literary Studies, 1(4). http://ojs.mediu.edu.my/index.php/AIJLLS/article/view/1471

Kim. E. (2006). Reason and Motivations for Code-Mixing and Code-Switching. Issues in EFL $4(1)$.

Liu, P. (2006). Code switching and code mixing. Retrieved May, 2020 from https://m.grin.com/document/92496\#BigPicturePanel

Meleong, L.J. (2005). Metode Penelitian Kaulitatif. Bandung: Remadja Rosda Karya.

Musyken, P. (2000). Bilingual Speech: A typology of Code Mixing. Cambridge: Cambridge University Press.

Purba, Y. H., Suyadi, S., \& Fitri, N. (2018). An Anlysis Of Code Mixing On Social Media Networking Used By The Fourth Semester Students Of English Education Study Program Batanghari University In Academic Year 2017/2018. JELT : Journal of English Lenguage Teaching, 2(2). http://jelt.unbari.ac.id/index.php/jelt/article/view/30

Satoto, S. (1999). Metode Penelitian Sastra. Surakarta: Universitas Sebelas Maret.

Sumarsono \& Pratana. (2004). Sosiolinguistik. Yogyakarta: Sabda

Safitri, L., Harida, E. S. \& Hamka, H. (2017). The Analysis of Code Mixing on Students' Facebook: A Study on Facebook Status and Comments of the Sixth Semester Students TBI IAIN Padangsidimpuan. Proceeding of ELTAR (English Language Teaching and Research Conference), 1(1). http://ejournal.unp.ac.id/index.php/eltar/article/view/8718

Stake, R. E. (2010). Qualitative Research. London: The Guilford Press.

Sugiyono. (2009). Stastistika Non-Parametris untuk Penelitian. Bandung: CV. Alfabeta. Wardhaugh, R. (2010). An Introduction to Sociolinguistics. Oxford: Blackwell Publishing Weinreich, U. (1963). Language in Contact: finding and Problem. New York: Mouton Publisher the Houge

Yunus. (2010). Jurnalistik Terapan. Bogor: Ghalia Indonesia. 